SAND78-0513

Unlimited Release

\title{
A System for Detecting Neutrons in the Harsh Radiation Environment of a Relativistic Electron Beam
}

Lyle W. Kruse 
Issued by Sandia Laboratories, operated for the United States Department of Energy by Sandia Corporation.

\section{NOTICE}

This report was prspared as an account of work sporsored by the United States Government. Neither the United States nor the Department of Energy, nor any of their employess, nor any of their contractors, subcontractors, or their employees, makes amy watrann. express or implied, or assumes any legal liability or responsibility for the accuracy, completeness or usefuiness of any infozmation, apparalus, product or process disclosed, or represents that its use would not infringe privately owned rights.

Printed in the United States of America

Avolable from

National Technical Information Service

U. S. Deparment of Commerce

5285 Port Royal Road

Springfield, VA 22161

Price: Printed Copy \$4.50: Mierofiche $\$ 3.00$ 


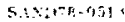

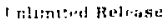

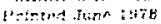

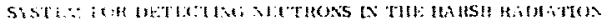

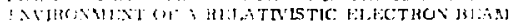

I Yl. W. K: Kuse

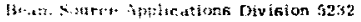

Sindi., J I.thnritorius

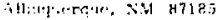

\section{Mis'rRac'r}

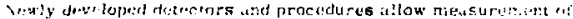

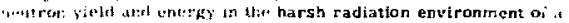
r:Litivistic oltetror beim source. A new photomultiplier tube "asik" ind spe-cial giating methols provide the basis for nowei timt-af-right and tolal-yield detectors. The technique of activiLom inuly: is is isunded to provite a reutron energy spectrom.

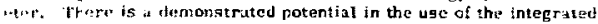

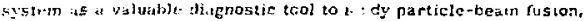

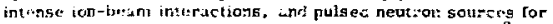
sirn:titing winpens reffects. A physical lower limi: of $10^{3}$ neutrone rito in is rstuls:s: for accurate and meaninglut measurements in the it IF envirariont. 


\section{ACKNOWLEDGMENTS}

The author wishes to thank the personnel of Sandia Simulation Instrumentation Divsion 1120 for cxcellent oscllloscope coverage of the electron heam tests. Acknowledgment is also due to J. M. Mckenzie and $R$. E. Jones of Sandin for thel invaluable assibtance in obtaining the code IUNFI.D and discussing its applications. With the help of these individuats, a difficult tiste becime. manaseable. 


\section{CONTENTS}

Page

Introduction

Section 1 - Syatems Development 9

Neutron Time-of-Elight 9

Total Neutron Yleld $\quad 12$

Neutron Activation Anaysis 19

Section II- Experimencal Results 19

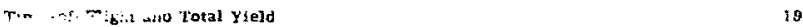

Full Systcm Measurements 22

Meaburement Uncertainties 24

Section III - Future Syatem Improvements 25

Section $\mathrm{W}$ - Conclusions $\quad 25$

$\begin{array}{ll}\text { References } & 26\end{array}$

APPENDLX A - Detalls of Detector Development

APP CinDIX B -- Discuesion of Computer Codes

ILLLSTRATIONS

Figure

1 Neutron Diagnostic System

Fisgion Neutron Energy Spectra Changea Produced by Varloug Thicknesses of Lead

Basic TOF Detector Congtruction $\quad 10$

Wiring of Photomaltipller Bage 11

Cross Section of Silver Activation Detector $\quad 12$

Total Yiejd Detector $\left(^{10_{B}}\right.$ liquid Bcintillator) 13

Detector Active Time 13

Dunctabje Neutron Yield Based on 200 Counts in a Photopeak During the Firat Hour of Deeny

Scope Traces of Detector Reaponse from Severa: HYDRA Experiments Distance of the Detector from the fiource 


\title{
A GYBTEM POR DETECTDG NEUTRONG DN THE HARSH RADLTTON ENYTRONMENT OF A RELATTVETLC ELECTRON BEAM
}

\author{
Introduction
}

Recentiy several laborajorleg have used relativiatic electron beam (REB) acceleratora to study controlled thermonuclear fugion, ${ }^{1}$ to generate Intense ton beame, ${ }^{2}$ and to provide reutron gurces for aimulation of weapong effects. ${ }^{3}$ Useful diagnostics for neutrons produced by $\mathrm{R}$ EB accelerators depend on detectora which can:

- Determine the total number of neutrong from a burst

- Deflne the temporal behavior of the neutrong

- Accurately determise the digtribution of neutron energy

- Detect neutrons with high efficlency

- Operate eatiefactortiy in the harsh electromagnetlc and $x$-ray environment of the REE.

Since a bingle detector could not meet the requirementa, three beparate aystems were combined to achieve the desired resulta:

- A neutron time-of-tlight spectrometer

- Detestore that determine total neutron yield

- A neutron energy spectrometer.

Several formidable problema related to background radiation mugt be overcome in order to detect neutrons from an REB experiment. Sources of the most serlous background radiation are:

- The intenae elactromagnetic pulee produced by the fast-pulae rlae times and bigh currenta of the advanced electron-beam fusion acceleratoro

- The large burgt of bremsetrahlung which can render certaln types of neutron detectors unelesg

- Nonthermonuclear neutrons, e.g., from photodialntegration or from interactions of ions accelerated by the diode fielda.

The most direct mathod to meagure the time higtory and, to some extent, energy distribution of a neutron pulee fo time-of-nlght. The ghort pulse of accelerator power (10- to $70-n g$ fun width half maximum) and short burn $(=4 \mathrm{ng}$ ) of the thermonuclear pellet require a fast detector. A ecintillation counter that combines a ecintillator and a photomultiplier tube can meet the responge time and detect neutrons with high effictency. 
In the high $x-$ ray background, time-of-Qlght (TOF) alone camot moet the detection ropulrements. Two additiond detectors provide the remainder of the neselang information. I rotalyield detector meagures the total number of neutrons independent of energy, An actiration andyole gystem, including a mult-materlal aample and a pneumatic transfer loop, is uned to obtu's neutron epectral information.

The complete neutron dfagnogtle gystem is thown in Flgure 1. The syatem operates according to the following sequence:

- The activation eampie is aent from the screened encionure to the irradiation point

- The accelerator fires, automatically gating the TOF and total-yrield detectors

- After the pulse, the activation sample is trangterred to the nounter within the screened enclogure

- Analygis begins as soon as the eample returns and continues for a predetarmined count period; during that period, raw data obtained by the detectore is analyzed to provide as much information as possible on the neutron apectrum

- Analysis reveals the specifle activity for each nuclide included in the sample

- Information on these specific activitieg, the time-of-night (TOF) and total yield le Input into an integral unfolding code which determines the number of neutrons as a function of energy.

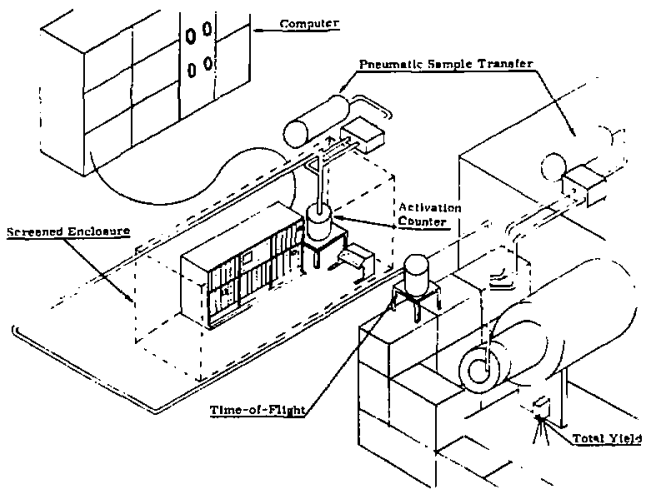

Flgure 1. Neutron Diagnoatic SyBtem 


\section{Neutron Time-of-Fight}

The $x$-ray background from a typteal $R E B$ is enough to overwhelm a bare photomuliplier tube. If a scintillator is added to the tube, $x$-rays completely gaturate the tube, making meseurements imposible. Shielding these detectors to prevent aaturation requires buch maseive amounts of lead that only high-neutron yields $\left(>10^{30}\right.$ ) can be detected. Arother problem with the use of lead shielding is the change of the neutron spectrum as shown in Flgure 2. Here, a fission neutron spectrum was measured after it had passed through lesd of varlous thicknesses. 4 Attenuation alone occurs to a thickness of $25 \mathrm{~cm}$, after whlch the neutron epectrum changes. Therefore, the TOF detectors uerc designed wth lese than $25 \mathrm{~cm}$ of shielding in order to maintain hlgh-detection efficiency and prevent spectral degradation.

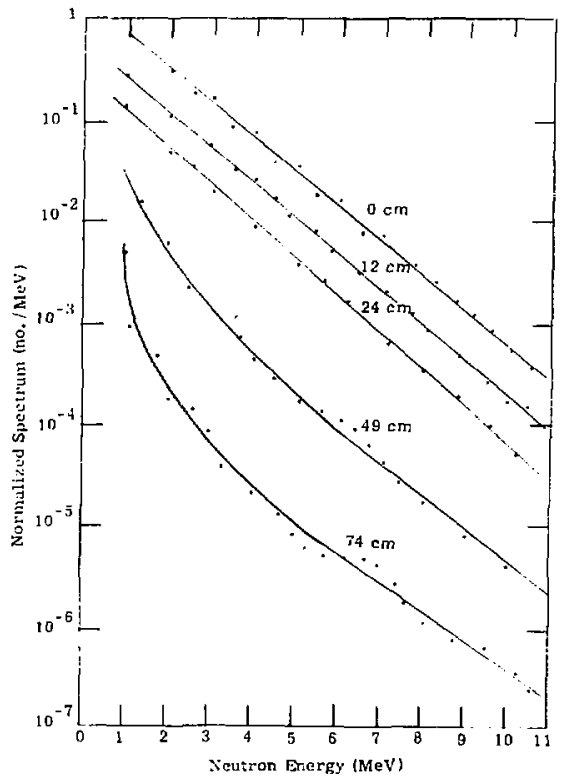

Figure 2. Fission Neutron Energy Spectra Changes Prodiced by Various Thicknesseg of Lead 
A substantial $x$-ray background remains even with $25 \mathrm{~cm}$ of lead. Since the $x$-say pulse arrives before the neutrons, proper gating precludes detcction of the remaining background while malntalning maximum neutron-detectien effieieney. Scveral methods for gating photomultiplier tubes have been reported. $5,6,7$ Most have deficiencies which make them unsuitable for REB applications. e.g., their turn-on times are too blow ajd/or the ettenuation ratio between thelr ON and OFF states is not high enough, In some instances, nonlinear response, ringing, and opurious pulseg were encountered.

In this wark, three gating methods were developed which elimivated these difficulties. Although all three are useful, only the last version, which uses an $\mathrm{KCA}^{8}$ photomultipller tube built to the author's specifications, performed well in the most severo $\mathrm{AEB}$ environment. Details of these gating methods are presented in Appendlx A.

Figure 3 shows the basic construction of the final TOF detector. The external shield-can reduces electrical noise. The $20 \mathrm{-cm}$ lead used for $\mathrm{x}$-ray shielding adequately excludes magnetic fields from the photomultipiler tube. Finally, a container that is $12 \mathrm{~cm}$ dia, by $12 \mathrm{~cm}$ long helds NE-224 ${ }^{9}$ liquid acintilator and is in intimate contact with the fuce of an RCA ${ }^{8} 7265+13$ photomultiplier tube.

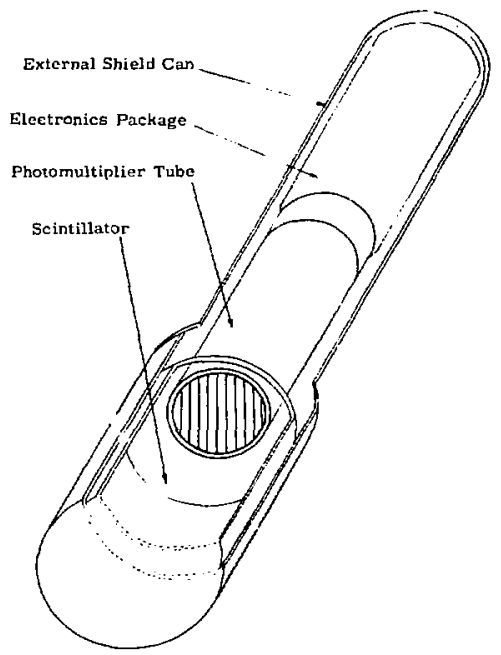

Figure 3. Basic TOF Detector Const ruction 
A eumbiration oi toc $=$ and byode control gateg the defector. Initrode GA-201-A bilicon $\therefore$ ontrol rectifiers (SCRg) ${ }^{10}$ are the activc control devices in the gating clircuit. Figure 4 fo a schematic shosting circult wiring details of the photomuluplier base. In ta OFF state, SCRs 1,2 , ind 7 reverse the biag of the nhotocathode-focus region of the tube and SCRs 3 and $f$ allow their respective dinotes to assume the potential of adjacen dynodes. In the OFF state, therelort, the SCFs exclude photocleteruis from the dynoute structurs, and eurtail dymode multiplication. The trigger pulse shown allows the SCRs to return the controlled electrodes to their proper potentials, thitrely guting the detector,

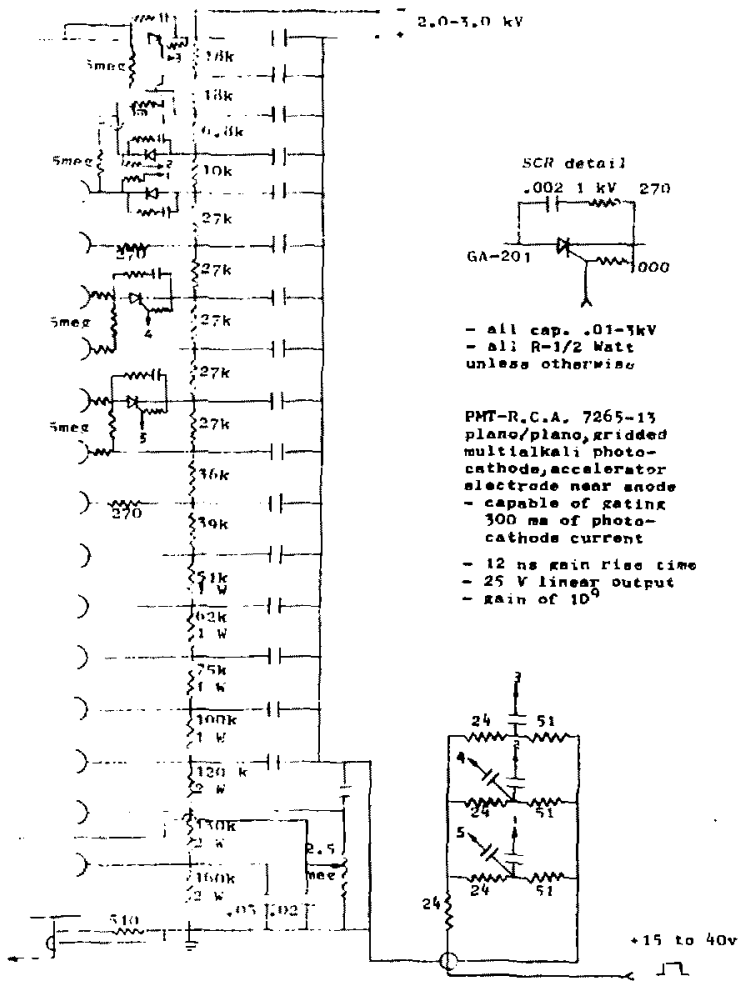

Figure 4. Wiring of Pholomultiplior Base 
Detalls of the reaponar of the TOF detector are Ireluded in sppendix $A$. The detector hise

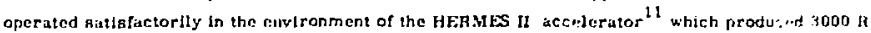
$x$-rity dofe at one meter. Deployed at a distaner of $7 \mathrm{~m}$, these deviecs were ahle to detert is few

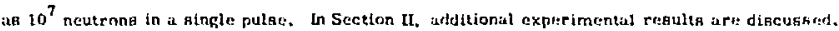

\section{Trtal Neutron Yiuld}

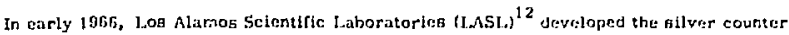
which has been wijely applied ag a total yield detector. Figure 5 phown a crogs-fectional yinw of the ailver-activatlon detector. Four Gelger Mueller (GM) tuhen in paralled are: individuially

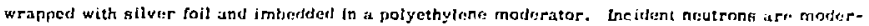
ated by the polyethylene and activate the gilver foll from the two captur; reactiona:

$$
\begin{aligned}
& { }^{107}{ }_{\mathrm{gg}\left(n, \beta^{-}\right)^{108} \mathrm{Cd}} \\
& { }^{109}{ }_{\Lambda_{g}\left(n, \beta^{-}\right)^{110}} \mathrm{Cd}
\end{aligned}
$$

A scaler counts the $\theta^{-}$decily for one minute after a neutron burst.

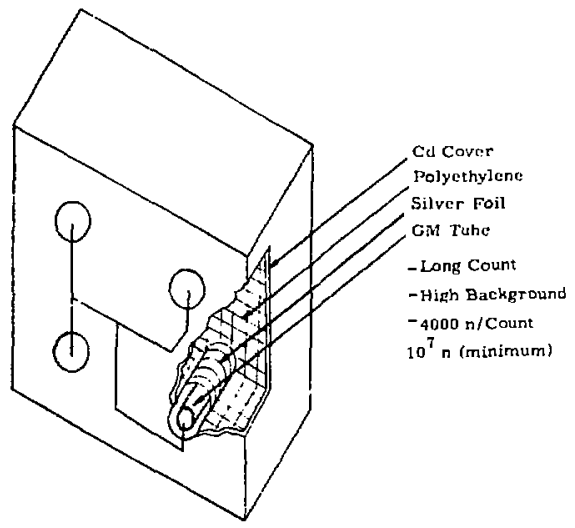

Figure 5. Cross Section of Silver Activation Detector 


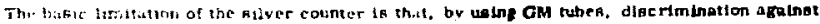

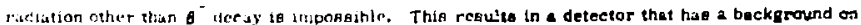

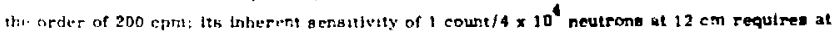

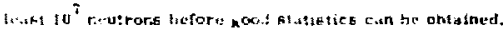

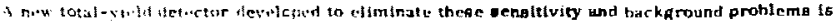

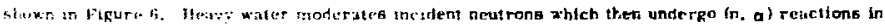

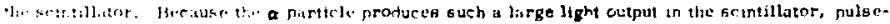

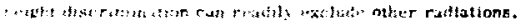

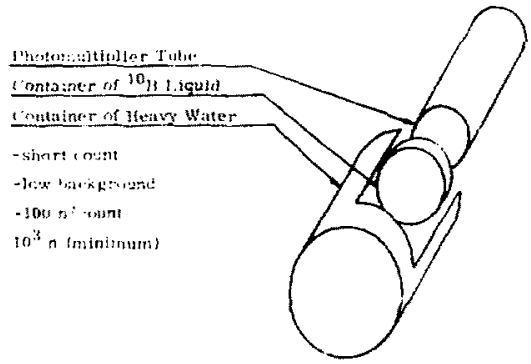

Figur: r. Totil Yinld Detector $1^{10} \mathrm{~B}$ tiquid scintillator?

Fifurl i shous the rharucteristic featurne of thermal neuten buldup and subsequent becay follos: $n_{5}$, furst. The time dolay between the initial hurst and peak population is the modoration tiru. $\left({ }_{m 1}\right)$. $\left.{ }^{2}\right)$ wis selected because the low capturs crose section provides the longest detertor

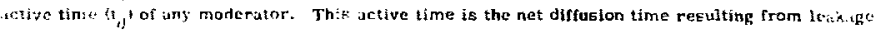

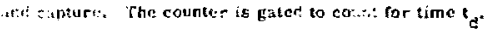

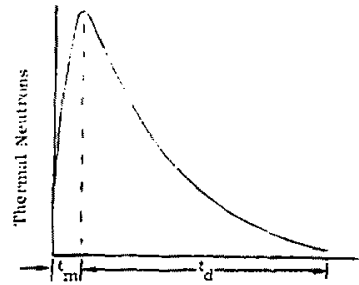

Figure 7, Detector Active Time 


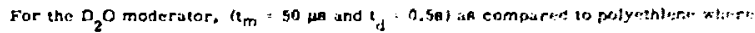

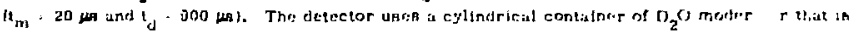

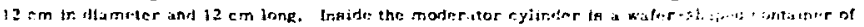

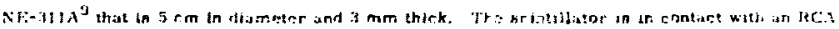

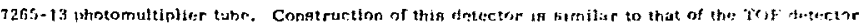

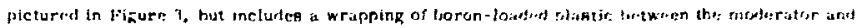

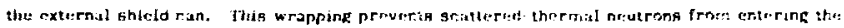
iletertor.

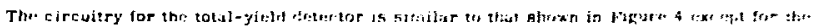

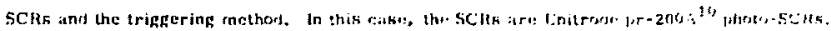

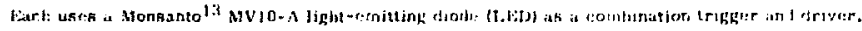

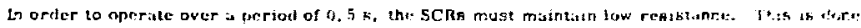

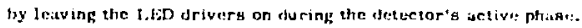

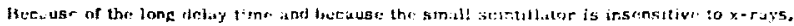

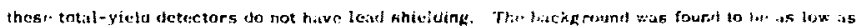

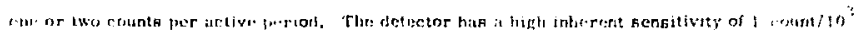

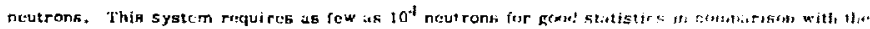
$10^{7}$ nededind ine the filluer rourter.

\section{Neutron Activation Analysts}

The trechnique of activation andys is has boen useat fre masy west fur numtron tosimetry as:r spectral analygis. ${ }^{14,15}$ Neutron activation is acromplishnd by essing nuclear reactions to chinge stuble: isotopes within a fiven sample into ratioactive isolopes. The ridistions emitied by the activition products are then mrisured and their spectra analyzrts. The detivation $5 y$ stern consisis of

A. A Rex-o-kabbit moumitic transfer ${ }^{16}$ systent for sample transfer.

1. Ar Ortce $6240^{13} 4096$-channcl multichannel anatyzer (Mch) and several singlechannel analyzers to anilyze the spectrum and measure the decaly constants of lise nuelides producci,

c. An interactive link to the Sandis Time-Share Computing System for handing and analyzing data.

By using a number of igctopes, each with different energy-rependent cross sectio s, is is por ible to infer the energy epectrum of the incident neutron beam, The differential nesiron spectrum can be obtaine; from the activated isotopes as a solution to the integral equation

$$
a_{1}=\int_{E_{1}}^{E_{h}} \sigma_{1}(E) \phi(E) d E
$$


$x+2+1 \cdot=$

$$
\begin{aligned}
& \text { a: is the activitiun of the } t \text { tt: fantope }
\end{aligned}
$$

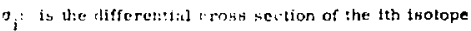

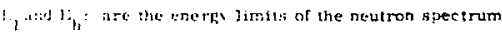

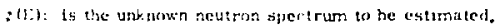

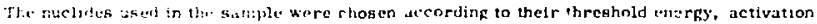

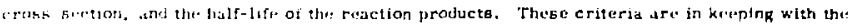

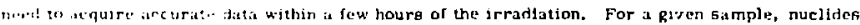

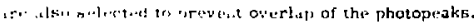

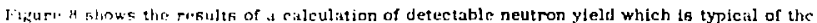

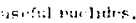

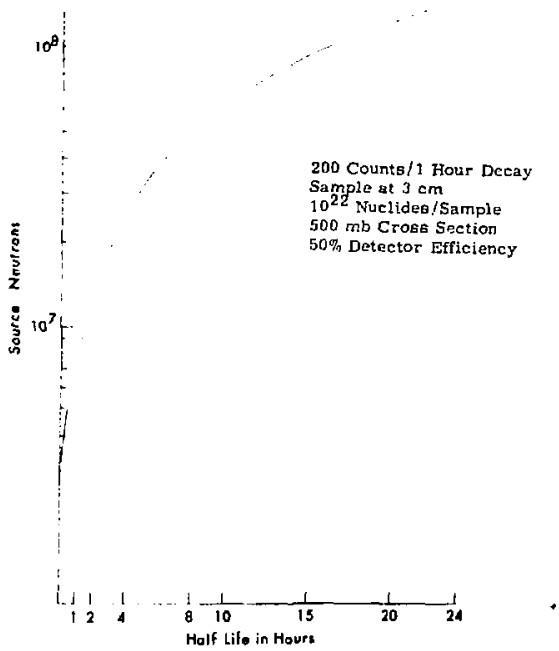

Figure 8. Detectable Neutron Yield Based oi 200 Counts in a Photopeak During the First Hour of Decay 


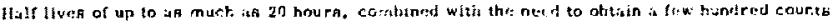

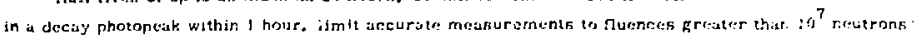
$\mathbf{m}^{2}$.

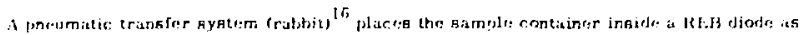

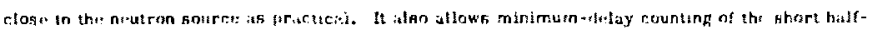

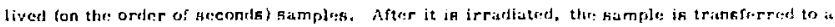
Gismmat Sprettroscony Syetern (GSS) to be meitaurieu.

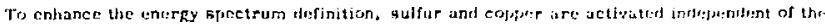

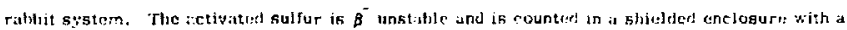

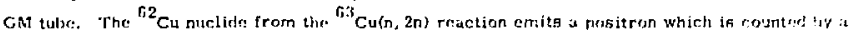

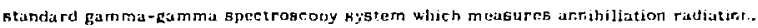

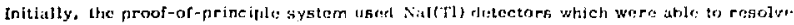
the photopeake of a muyimum of four nuctides per rabbit sanple. Tfrest: samples phlus the coppur

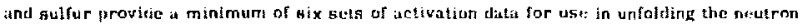
spectruns.

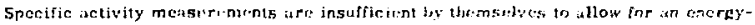

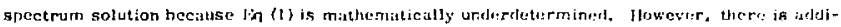
tional information relative to $t$ (l:) which can bet ustos to solve the zquition.

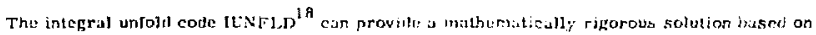

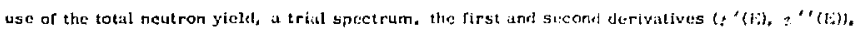
and equality or thequality constraints such is $\in(0)=0$, or $\neq(1,2) 0$, fiven an בproximation to the above quantitics is uscful, provided their uncertainties are known. The cote has the capability of weighting the data according to its uncertainty. Propagation of the weights through 1 \& IUNFLD stutistical packnge provides the busis for assigning a confidence lubel io the unfolrdel spectrum.

Data obtained from the TOF and the total-yicle systems e:an provide the additional information reguired to achieve a solution. Total-yictd gives the total inceral which consirains the solution. The TOF data provides inequality constraints so that $\neq$ ' $(E)$ can be estimated, Although the magnitude of : (E) may be uncertsin, in practice krowing the direction or sign of $A^{\prime}(E)$ aids the sa!ution.

IUNFLD reprcsents $2(E)$ as a linear sum of basis lunctions according to the equation

$$
q(E)=\sum_{J=1}^{N} c_{j} D_{j}(E)
$$


where

$$
\begin{aligned}
& \text { 5) (E): arc the baste functlons } \\
& i \text { : are umplitude terms } \\
& \therefore: \text { is the number of tunctions }
\end{aligned}
$$

5iri. the distrioution of the tasis functions is soriewhat arbitrary, proper selection can be usect 10 advintage. The corte cun he started by plucing more than one bisis fun."ion near at atucture

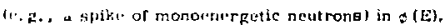




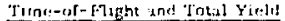

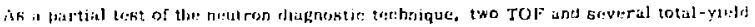

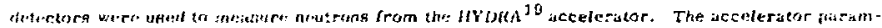

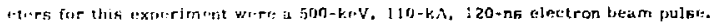

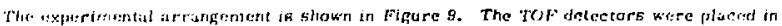

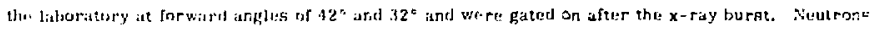

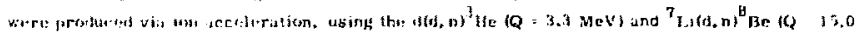

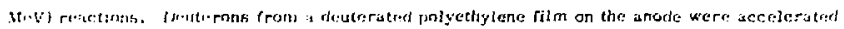

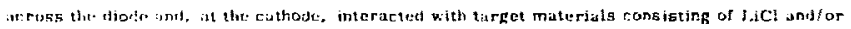
Iits

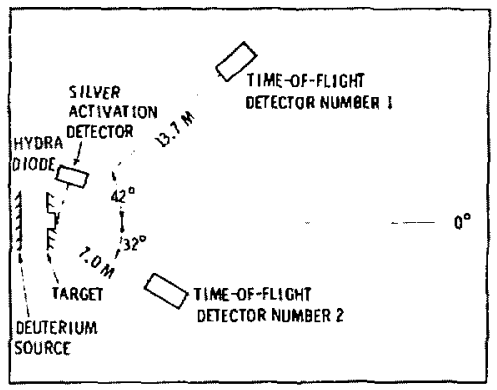

Figure 9. Schematic of the Fexperimental layout Used for IJYIRA Meisurement. The anode-cathode separation was $1 \mathrm{~cm}$.

Theso roaction inechanisms could be expected to occur with the failure of a fusion-target. experiment. Should the target leak, fail to compress properly, or disassemble, deuterium and/or tritium woutl enter the diode. The ions thus released would be accelerated by the fields in the diode und would interact to produce neutrons of non-thermonuclear origin. In general these neutrol:s will possess large amounts of center-ofm mass energy urd will be distributed anisotropically. TOF deployment at different angles and distances can ciscriminate hoth of thege effects, 
Figure 10 ahowe 'rOF data for geveral poasible reactions. When there is no neutron + piroductng material in the diode, no algnal is preant from either detector. The apectrum for the d-Li twr may be noted to be a composite of the fpectra of the deuterium and hithium targets respectuvely.

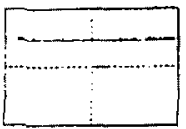

(d)

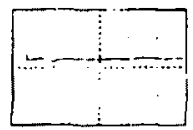

MO IOR LI IN DIODF
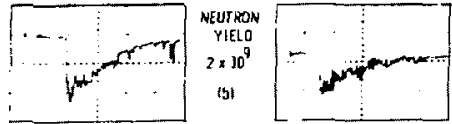

A SOURCELI TARGE
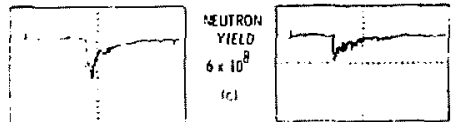

A SOURCEIO TARCET
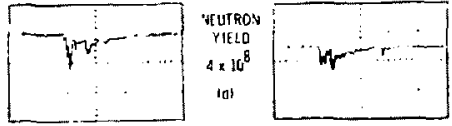

C SCURL: 'd - II TRRUtT

Figure 10. Scope Traces of Detector Response from Several HYDRA Experiments. The graphs on the left co:respond to detector 1 and those on the right to detector 2 . The bharp positive pulse at the beginning of the traces is a timing fiducial point. All aweeps are at $400 \mathrm{~ns} / \mathrm{div}$ and $4.0 \mathrm{v} / \mathrm{div}$.

Timing information obtained from shots in which both neutron groups are present is iliustrated in Figure 11. The neutron arrival time at each detector is plotted againgt the detector's digtance from the source. Instrumental delay times have been remeved. Each data point if averaged from three shots and the eize of each square represents the error in measurement. Ttie arrow Indicated the time at which diode current begins to rise in the accelerator. 


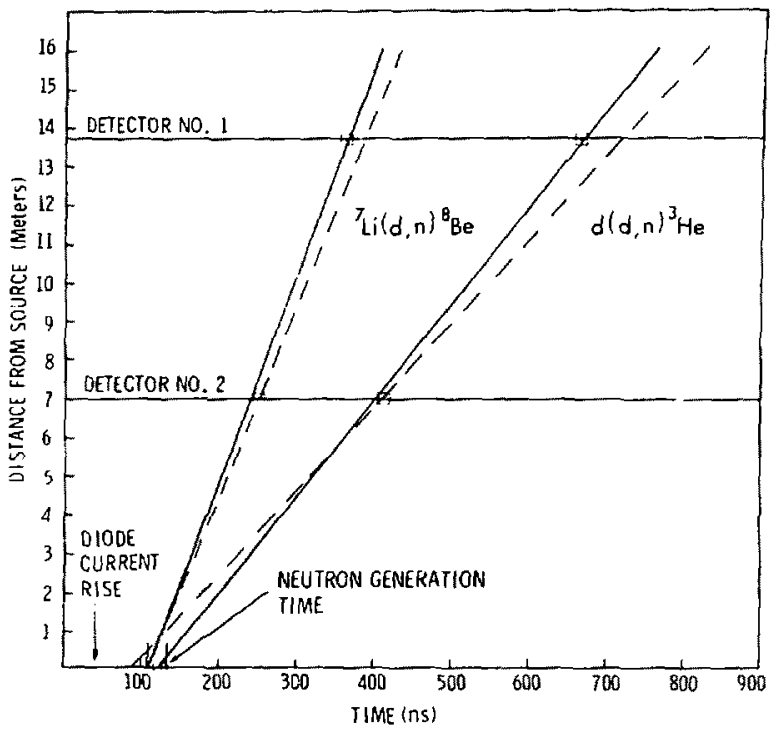

fitum 11, Arrivul Timb of a Neutran Groun at the Detector Plotted Against the Distunce of the Detcetor trom the Source

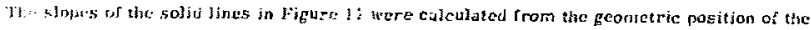

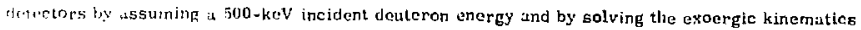
"psitioxy for the metions. InLsi" slopes were then drawn through the datu to be consistent with

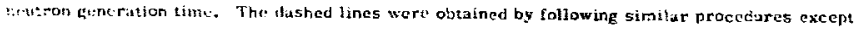
this thermil linergies werc issumed for the deutcrons.

The time of ini:istion of neutron generation, deduced from the solid lines, is the same for luth neutron groups within the exporimental accuracy. This generation time agrees well with indefendent Faraday-cup measurements ${ }^{20}$ of the ion current at the cathode. The fit of the solid iires to the datic (Pigure 13 ) ard the anisotropy (Figure 10) clearly indicate an incident deuteron energy of joo kev. 
The rOF detectors are deployed at different ungles to the diode axis so that leotropic fusion

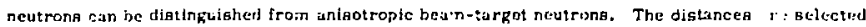
to faciltalc metasurement of neutron conter-of-mass anergy. Thase diatunces reprogent is required minimum yield of $10^{7}$ neutrons for this cxperiment.

\section{Full System Mcasurementf}

is a further teat of the full system, an experimen: was performed using the three types of

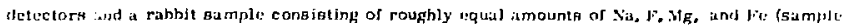

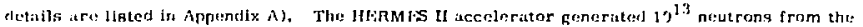

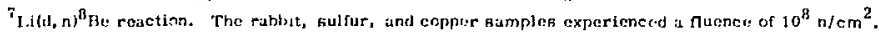

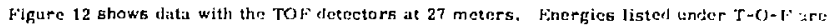
tleduced from the labeled structire of the scope triseus, Maximum expected energinf us rislculatrat from the kinematics cquations iare also listed.

(i)

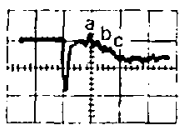

$4.0 \mathrm{~V} / \mathrm{div} 400 \mathrm{~ns} / \mathrm{div}$

$$
{ }^{13} \mathrm{C}(\mathrm{P}, \mathrm{N}){ }^{13} \mathrm{~N}
$$

(b)

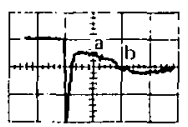

$4.0 \mathrm{~V} / \mathrm{div} 400 \mathrm{~ns} / \mathrm{div}$

$$
{ }^{12} \mathrm{C}(\mathrm{D}, \mathrm{N})^{13} \mathrm{~N}
$$

(c)

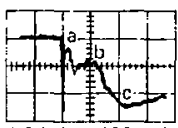

$4.0 \mathrm{~V} / \mathrm{div} 400 \mathrm{~ns} / \mathrm{div}$ ${ }^{7} \operatorname{Li}(O, N)^{8} \mathrm{Be}$

\begin{tabular}{|c|c|}
\hline $\begin{array}{l}\text { Energy } \\
\text { (MeV) }\end{array}$ & $\begin{array}{l}\text { Energy } \\
\text { MeV) }\end{array}$ \\
\hline a 4.19 & $4.7 \max$ \\
\hline
\end{tabular}

\begin{tabular}{lll|l} 
T & $-O$ & $F$ & Kinematice \\
Energy & Energy \\
(MeV) & MeV) \\
a & 3.9 & \\
b & 3.1 & $2.5 \mathrm{misx}$ \\
C & 2.0 &
\end{tabular}

\begin{tabular}{|c|c|}
\hline $\begin{array}{l}\text { Energy } \\
(\mathrm{MeV})\end{array}$ & $\begin{array}{l}\text { Energy } \\
\text { (MeV) }\end{array}$ \\
\hline a 9.34 & \\
\hline b 2.96 & 153 max \\
\hline c $\quad 1.8$ & \\
\hline \multicolumn{2}{|c|}{ Production of ${ }^{8} \mathrm{Be}$} \\
\hline
\end{tabular}

Production of $13_{\mathrm{N}}$.

Figure 12. Scope Traces, Time-of-Flight Neutron Dnergies, and Kinematic Energies for the Three Reections Induced by the HERM II Accelecator 


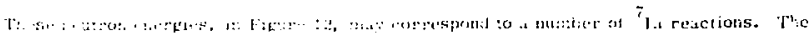

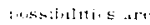

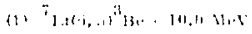

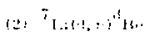

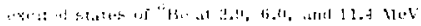

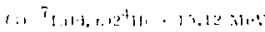

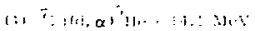

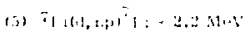

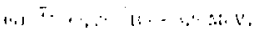

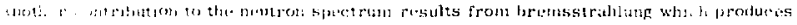

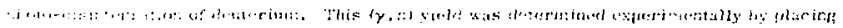

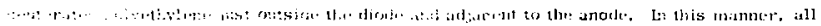

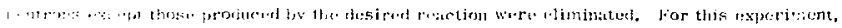

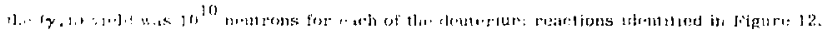

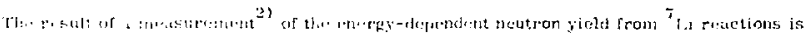

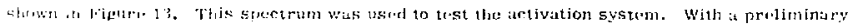

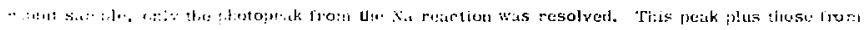

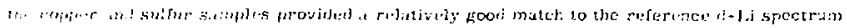

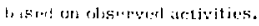

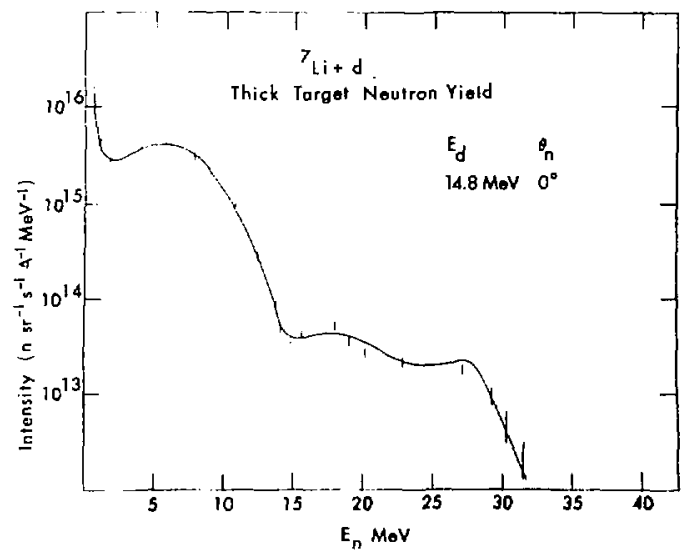

Figure 13. Neutron Yield by ${ }^{7}$ Li Reactions 
netivation neake from three other groups of nuclides in the rabbit were masked hy the coinclence-sum eflect of the Nill(TI) well-erystal which was used as a detector (this ats it is discueged in Appendix Al. AE a reaule, insufficient information was avalahte for IUN FLD to wroduer a solution. To provide the hest possibli: speetru'i, suiution. is higher resaltuion detector system is beang devclopeu.

\section{Measurement Iincertaintics}

The dominikt uncertaintics in the measurements are related to;

- TOF neutron encray Uetermination

- Cross gection uncertianties

- Matik handling procedurea.

Her yields on the order of $10^{7}$ to $10^{8}$ neutrons, the exoergic energy release cinnot is metasured to great accuracy. This uncertidinty has been iound to be approximatoly $\pm 5 n$ keV for all incident ion energies above $200 \mathrm{keV}$. As the total yield increaseb, iccuracy is li aited to an energy inc rement corresponding to 10 percent of the TOF oscilloscope sweep spreed or to the dotector. response timc, whichever is greatcr. When a $50-\mathrm{r} / \mathrm{s} / \mathrm{cm}$ aweep is usiod, for example. thF is ususly limited to $\mathbf{t} 5$ us. For faster sweeps, overall aceuracy is limited by the detector respons: time of 2 ns.

The total-yicld detuctors are calibrated with monconeractic neutron sources. The seuttering cross section varietion of $\mathrm{D}_{z} \mathrm{O}$ couplet with the luck of hnow]edge of the experimental spertrum limits tolal-yield accuracy to a luctor of two. This fuctor is the tolerance which is input to 1UNFI,D. For the sperial case of monoenergetic neutrons, total $y$ icld can be measured to within \pm 15 pereent.

The lorgest sources of error in the activation analysts are bascd on cross-section unctartainiy and the behavior ef the PEA KDAT code for the NuI(T) detector datis. The eross sections for the reselions listed in Table $\lambda-2$ are $\$ 10$ percent acturate. Is show in Appendix $B$, PENKDAT will culculate speciftc activity to within $\neq 6$ percent. The sum of thesc is used as a best estimate tole rance of \pm 16 percent for IUNFLD.

The uncertainty of the IUNFLD solution is not the same as the cumblative error from the measurements. Since ILNFLD effects a minimal-norm solution to the given data within tolerances, the Chi-squared output prouides a confidence level to which the solution apectrum can be believed. For the differential spectrum. values of 70 to 30 percent are good with the lotter considered excellent $180 \%$ confidence is best thought of as obtaining the same spectrum, within tolerance, g0 times if the experiment were conducted 100 times). Values near or in the 90 percent range are unrealistic because uncertainties in the data do not justify such confidence in the results. ${ }^{23}$ 
To overome defficulites wilerienced when measuring activation, a nitw detector system is

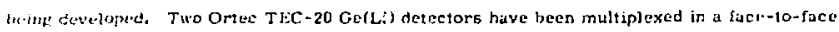
a'o:u+try. ilthough this systers his in overall efficiercy of only 28 percent of that of a NuI(TI).

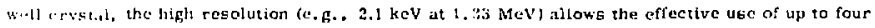
timi-s as my nuclides per sample, The decreased efficitacy coupled with an increased peak-tocompton r.tio combiac to reduce the ininimum detectable nvence by a factor of only two. Thera.

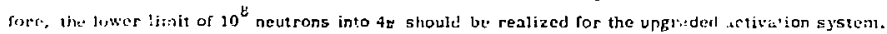

\section{Section IV. Canclusions}

I heutron ffetection system capable of operating in the harsh ridia,ion ervironment of a $H$ HB has bon tleveloped and tested, By employing three different types of detectors, the system ean perform toncrgy-spertrum and total-yield measurements.

If a single ineasure...erit (using only cne method) were made. the itherent limitations or the hetuctors woula make it diffieult to meet the requiremerts outlined earliet. The difficul: task of characterizing neutrons in the RES environment has been accomplished by developing a consistrint sit of pirameters from the ma:y complimentary measurements. 


\section{Refe rences}

1. G. Yonar et ai, Nugl, Fuston 14, 731 (2074).

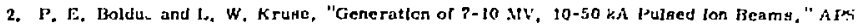
Plnsina Physics stecting, :Nev.11977).

3. P. E. Boldue and I, W. Kruar, to be published.

4. V. N. Avaev ct al, Atomnajn Encrgtja 15, 20 (1963).

5. K. 13. Keller. Rev. Sci, Inbtrum. 35, i360 (105A).

f. G. Charpak, Nucl, instrum. Noth, it, 175 (1907).

7. D. Ben-Zeev et a1. Nuc]. Ingtrum, Meth, 114, 513 (1974),

B. nCA is a regtstored trademark of RCA Elcctronlc Componarta, Itarrison. Nit o70z?.

9. Avalable from Nuclear Enterprises lnc., 935 Terminal Way, Sun Carlos, CA y4u70.

10. Unitrode is a reuistered trademark of Unftrode Corp., Watertown, A1A 02172.

11. T. If. Martin, K. A. Prestwieh, and D. L. Johnson, "Summary of the Hermes Fash X-fay Prograrn," SC-RR-60-421. Sandia Laboratories, Oct.(1069).

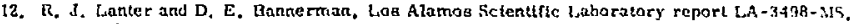
July 1966.

13. Monsanto Corp. 10131 Bubb Rond, Cupertino. CA 95917.

14. Nargol Walla and Przybylowiez. Activation Analysis with Neutron Generatorg, John Wiley d Sons (1973).

15. P. Kruger. Principlea of Activation Analygig, John Wiley Sons (1971).

16. Reactor Experiments Ine, 963 Terminal Way, San Carlos, CA 94070.

17. Ortec Jnc., 100 Midland Road, Oak Ridge, TN 37B30.

1B. F. Biggs and D. Amos, IUNFLD, "Numerical Solution of Integral Equations and Curve, Figging," SC-RR-71-0212 and SAND77-013G, September 1971, and R. E. Jones, J. M. AcKenzie, and $\mathbf{L}$. A. Romero, "Differentlal Neutron Spectra Unfolding from Foil Activation Data," IECE, Proc. Nuc, Sci,. Dec, 1977.

19. J. J. Ramirez and L. W. Kruse, Rev, Sel. Inst, 47, 832 (1976),

20. D. W. Swain, L. P. Mix, L. W. Kruge, and $J$. W. Poukey. "Measurements of Large lon Currents in a Pinched REB Diode," Journal of Applied Physice, pp. 48, 1iB (3977).

21. NI, A, Lone et al, Nucl, Inst, and Moth. 143, 331 (1977).

22. R. L. Heath, "Scintillation Spectrometry Gamma-Ray Spectrum Catalog," IDO-16860, Vol, 1 \{1064\}.

23. R, E. Jones, private communication (March 1978). 


\section{A P'ESDDA $A$}

Detall of fretector Development

fi:

I: ea rilt: versiun of TOF detectors uad a $12.7-\mathrm{cm}-$ diam $\times 12.7$-cm long plistic scintilla-

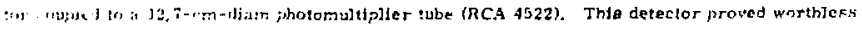
when :xf. zitei to the Hermes It environment.

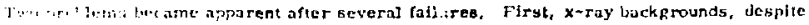
$\therefore$. Ir: shicluing, was intenge enough fn cuuse the high-rebletivity $\mathrm{S}-\mathrm{il}$ photocathode of the

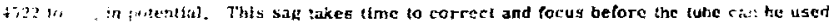

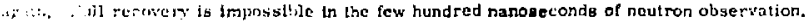

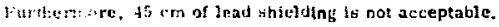

Io overconc lig problem, a new photomultiplier tube was fabrlcated to my specificitions by

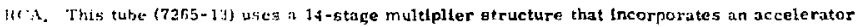

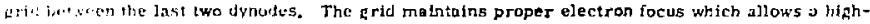

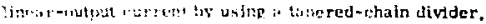

The pholocathode is multialkali ( $\mathrm{Na}-\mathrm{K}-\mathrm{Cs}-\mathrm{Sb}$ ) with Iower realetivity than an $5-11$ cathode. In additinn, an Internal metalle grid is deposifed over the photocathode go that if local $6 a g$ occurs. proper focus is maintuiled.

A plano-plano front end reduces the high capactance which lo normally present in a sphericalfection input such is the $\mathbf{4 5 2 2}$. This feature greatly reduces switching times when controlling the focus region of a photomiltiplier tube,

it room temperature, a normal S- 11 photocathode whll ogg in potential with $10^{-8} \mathrm{~A}$ of $\mathrm{Bteady}$ photocathode current. It was fotind to $\mathrm{sag}$ at $63-\mu \mathrm{A}$ 120-na pulsed curreat from fERMES If

The work function of the modifted photocathode ts approxtmately $1.1 \mathrm{eV}$. Since scintilator photons are predomlnately $2.7 \mathrm{eV}, 1.6 \mathrm{eV}$ photoelectrons are generated at the photocathode. In the OFF state (Figure $A 1$ ), dynode 1 and the focus plane are tled together to prevent a potential well. These electrodes are then tied to $+52,4 \mathrm{~V}$. The photocathode fo Hed to +104. $\mathrm{V}$ regulting in the reverse field shown in Figure $\mathbf{A} 1$. 


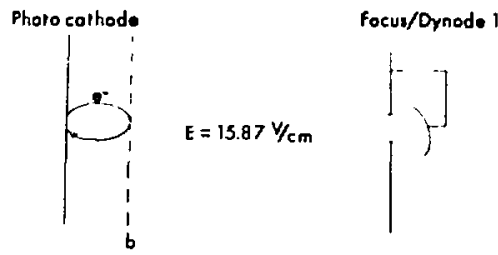

Higure Al. Heverse lshaged finess hegion

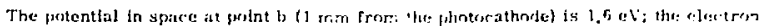
trajectory shown can be calculaterl as:

$$
\text { initial vejority: } \begin{aligned}
1 / 2 \mathrm{mv} & =K E \Rightarrow v=\frac{2\left(1.6 \times 10^{-19}\right)(1.6 \times v)}{0.11 \times 10^{-31} \mu 5} \\
V & =7.49 \times 10^{5} \mathrm{~m} / \mathrm{s}
\end{aligned}
$$

At point b the electron velocity is zero so the field acceleration ren be calculared

$$
0=v=\left(7,49 \times 10^{5}\right)^{2}+2(-a)\left(1 \times 10^{-3}\right) \Rightarrow \mathrm{n}=-2.81 \times 10^{14} \mathrm{~m} / \mathrm{s}
$$

Time from electron cmission to subsequent collection at the photocathode in the $O F F$ stiste $i$ - then:

$$
\begin{aligned}
& \left(-2.81 \times 10^{14}\right) t^{2}+\left(6.38 \times 10^{5}\right) t=0 \\
& t=\frac{8.38 \times 10^{5}}{2.81 \times 10^{14}}=2.96 \mathrm{~ns}
\end{aligned}
$$

This single electron treatment is valid only to the 1 lmit of the space charge which can be sustained under these conditions. The space charge-limited curren: car, easily be calculated for the plano-plano front end as:

$$
\begin{aligned}
& t b=\frac{2.336 \times 10^{6} \mathrm{eb}^{3 / 2}}{d^{2}}\left(\mathrm{amp} / \mathrm{cm}^{2}\right) \\
& \mathbf{l b}=\frac{2.336 \times 10^{6}(15.97)^{3 / 2} 17.35 \mathrm{~cm}^{2}}{(3.3)^{2}} \\
& t b=235 \times 10^{-6} \mathrm{~A} .
\end{aligned}
$$




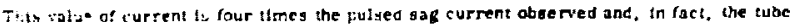

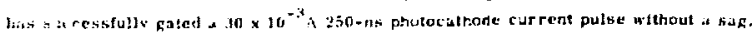

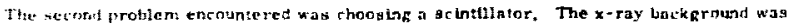

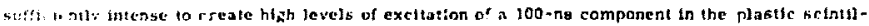

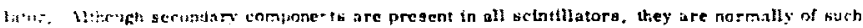

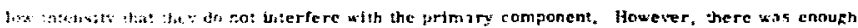

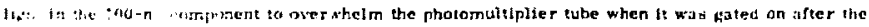

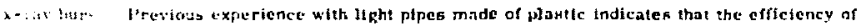

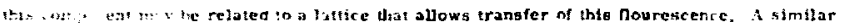

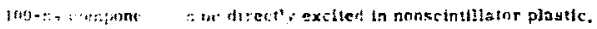

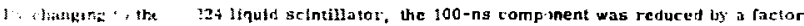

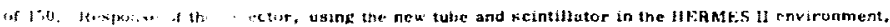

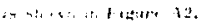

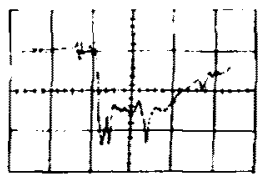

$4 \times 10^{8}$ total neutrons $d-d$ and $d^{7}-{ }^{7}+$.

$1,6 \mathrm{~V} / \mathrm{d}$ : $100 \mathrm{~ns} / \mathrm{dlv}$

Figure 12. Uetec tor Response in HERMES U Environment

If was finally determined that when gating is done only by controlling the dynodes, as with carlicr detector versians. It is not enough to prevent saturation of the photomultiplier tube. idding the reverse-bias sront end resulted in such insensitivity to saturation that the Tor detector tinally chosen has wot become saturated even with a total dose of 2000 Rad in 120 ns, Fast Euttching times and linear response have not suffered; detector rise time from OFF ta oN state is $16 \mathrm{~ns}$, the signal rise time $2 \mathrm{~ns}$, and linear outpet $1,2 \mathrm{~A}$ into $50 \mathrm{ohms}$.

\section{Activation Analysis}

As previously mentioned, samples to be activated are constructed by loading a Rabbit capsule with a homogeneous mechanical mix of powder containing the footopes. Table Al shows two samples suitable for VallTI). 
TARLE AI

\section{Retivation Somples}

\begin{tabular}{|c|c|c|}
\hline \multirow{5}{*}{ Sample ? } & Nuellde & $\begin{array}{l}\text { Number Dengity } \\
\text { (atoms } / \mathrm{cm}^{3} \text { ) }\end{array}$ \\
\hline & $N i$ & $4.75 \times 10^{21}$ \\
\hline & Si & $7.55 \times 10^{21}$ \\
\hline & Mts & $9.52 \times 10^{21}$ \\
\hline & 0 & $2.84 \times 10^{22}$ \\
\hline \multirow{4}{*}{ Sample 2} & $\mathrm{Na}$ & $3.55 \times 10^{22}$ \\
\hline & $r$ & $1.55 \times 10^{22}$ \\
\hline & $M_{R}$ & $1,: 9 \times 10^{22}$ \\
\hline & !c & $1.75 \times 10^{22}$ \\
\hline
\end{tabular}

The compounds, such as $S_{1} \mathrm{O}_{2}, M_{5} \mathrm{O}$, and Nar., are powders so that the final number densitics ore slightly lower than normal solid densities.

Tho detector chosen for the early lests was. TXiltil), well crystal, but the coincielencesum of the principle radialions from the high-speed sample masked all but the lowest energies, such is the $439-k e y^{3}$ photopeak from the ${ }^{23} \mathrm{Na}(\mathrm{n}, \mathrm{p})^{23} \mathrm{Ne}$ reaction. Mthough this effect is discussed by Heath, ${ }^{22}$ its severity is best illustrated in Pigure $A 3$,

Figure $A 3$ thustrates two separate spectrum results from a standard 0.1 uCl ${ }^{22}$. Na source. The source has the same physical dimensions as the Rabbit capsule and was placed inside the well to obtal A3(a). The same source, on the face of the detector, yielded A3(b). Nothing in published literature Indicated that the full energy summation could be as severe as discovered. Therefore, despite low cost, this type of detector is clearly not acceptable for multinuclide analysis.

Multiplexing two veli detectors in a face-to-face geometry maintains good elficiency while climinating coincidence-sum effects. Nhthough total price is higher, it is probably the only reasonable choice. 

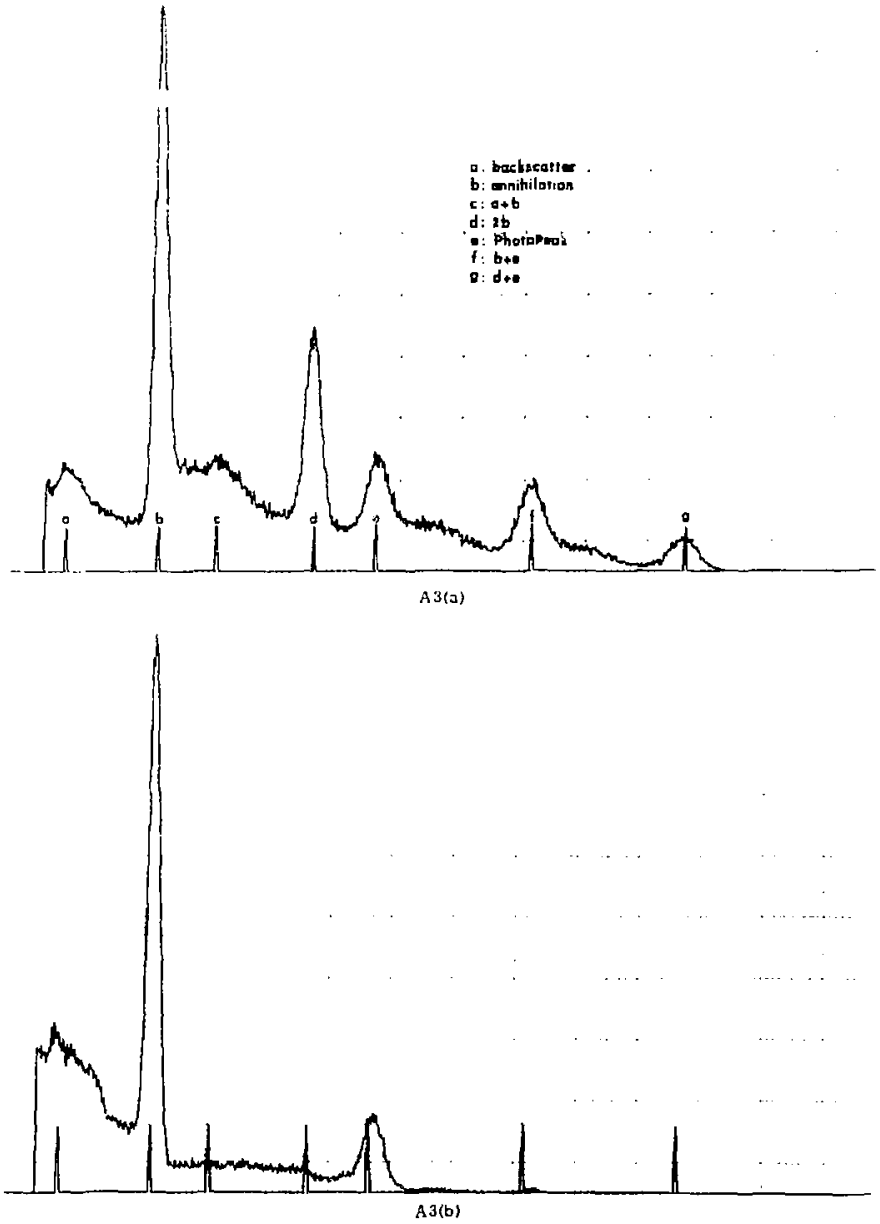

Figure A3, Nal(T1) Colncidence-5um Effect

31 
AB a find 25pect, the pncumatic transfer eystem allowg activation products with a short

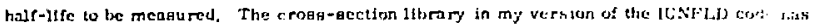

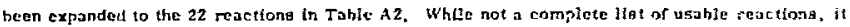
repracente the types of applicahle reactions, In addition to the nuclide selection criterion previously discusged, uncertalnty of crosa-Bection valuca is the single largest hource of errars is activation analyols, For this reagon, not all nuclides which survived priss tcats are suttable fror uec. It is not uncomnasi in some cases to flnd crass-sectlon volieg which art unectoin by as

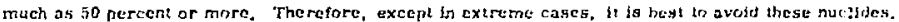

TARLE $A 2$

\begin{tabular}{|c|c|c|c|}
\hline IUNets $p$ & ofl $\mathrm{No}$ & Sonfiguration & Reaction \\
\hline${ }^{239} \mathrm{ru}$ & 1 & $\mathrm{e}^{10}+\mathrm{rd}$ cover & $(n, f)$ \\
\hline $23 B_{U}$ & 2 & $\mathrm{Cs}^{10}+\mathrm{Cd}$ cover & $(n, n)$ \\
\hline D3 Np & 3 & $6^{10}+c d$ cover & $(n, r)$ \\
\hline${ }^{32} s$ & 4 & Hare & $(n, p)$ \\
\hline${ }^{235} U$ & 5 & $\mathrm{~s}^{10}+c$ cl cover & $(n . n)$ \\
\hline $58 \mathrm{Vi}$ & 6 & Bare & $(n, p)$ \\
\hline${ }^{55} \mathrm{Fe}$ & 7 & l3are & $(n, p)$ \\
\hline $2+{ }_{215}$ & 8 & Barc & $\{n, p)$ \\
\hline${ }^{23} \mathrm{No}_{\mathrm{N}}$ & 0 & Cul cover & $(\pi, y)$ \\
\hline${ }^{27} \mathrm{AI}$ & 10 & 13are & $\{n, a\}$ \\
\hline${ }^{54} \mathrm{Fe}$ & 11 & llare & $\langle n, p\rangle$ \\
\hline $115_{\mathrm{In}}$ & 12 & Bare & $(n, \gamma)$ \\
\hline $232_{\mathrm{Th}}$ & 13 & Cd cover & $\{n,[\}$ \\
\hline $127_{I}$ & 14 & Bare & $(\mathrm{n}, \gamma)$ \\
\hline${ }^{28} \mathrm{Si}$ & 15 & Bare & $(n, p)$ \\
\hline${ }^{16} 0$ & 16 & Bare & $(n, p)$ \\
\hline${ }^{23} \mathrm{Na}$ & $x t$ & Bare & $(n, p)$ \\
\hline${ }^{23} \mathrm{Na}$ & $1 \mathrm{~B}$ & Bare & $(n, \alpha)$ \\
\hline $10_{F}$ & 19 & Bare & $(n, p)$ \\
\hline${ }^{19} \mathrm{~F}$ & 20 & Bare & $(n, \alpha)$ \\
\hline${ }^{65} \mathrm{Cu}$ & 21 & Bare & $\{n, 2 n\}$ \\
\hline${ }^{63} \mathrm{Ca}$ & 22 & Bare & $\langle n, 2 n\rangle$ \\
\hline
\end{tabular}




\section{A PFENDEX $\mathbf{B}$}

Discussion of Computer Coden

Program PEAKDAT Prineaut

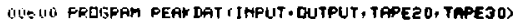

(UIST 10 DIMEHSIDH BAD ( 10$)$

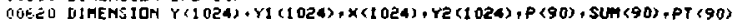

(1): 3 ति CAL $=3.040^{\circ}$

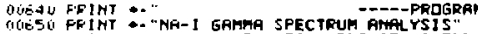

START-2-m-"

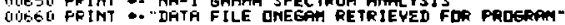

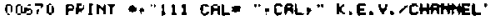

UTESO TFLL GETF (IECEl,20.EHOHEEAT)

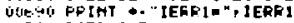

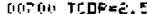

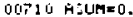

INUTE' TER $=7$.

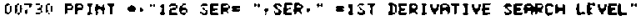

Qui. 4n P=5.

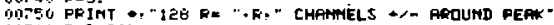

DOTSEO E=POCAL

UINTTO FEAD $(20.23\rangle\langle\gamma\langle 1\rangle \cdot(=1 \cdot 1024\rangle$

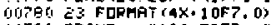

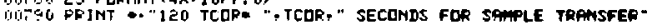

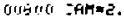

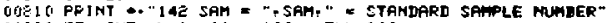

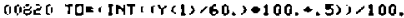

$00330 \mathrm{~T}=\mathrm{T}(1,2+1-1$.

00840 PPIHT -. "LIVE TIME = ". TO:" MIMUTES"

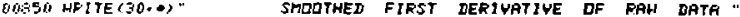

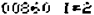

OOSTO ISE ASUM-ASUM-YAT)

1) $(038(1) \quad \because(I)=1$

nos?to $I=1+1$

nộl If $(1-10 E 4)+5 z \cdot 160 \cdot 160$

$00910160 \mathrm{j}=\mathrm{e}$

atisa $\quad l \in 1 \quad l=1+1$

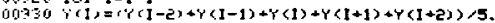

r. 1040 IF $11-1022) 161: 164: 164$

cựs $154 \quad I=0$

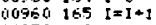

vition $\quad 1=0$

(1)

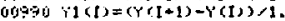

n1000 If $(I-1024) 165: 181+181$

01011 181 CFLL GETF (JERR1, 20.6HOHEGAT)

Q1 OEU PRINT *." "

01 U30 PEAD (20.23) (Y (I) : :=1,1024)

OtO40 190 COHTINUE

$01050 I=60$

01060192 IF (I-1024) 194.340.340

01070194 IF $Y$ Y (I)-SER) 200:220,220

01080 200 $1=1+1$

01090 G T 196

$0 ! 100$ 2E0 IF (YI (I) - 0.) 250:250,230

01110 E30 $I=I+1$

01120 G TD EeD

$01130250 \mathrm{~J}=\mathrm{J}+1$

$01140 \quad P(J)=I$

$0 \pm 150$ PRINT *." ".

OIIGO PRIHT \&, "LUCATIOH OF PEAK IS CHAHEL ",P〈J〉

01170 HEP (J) $\triangle$ CAL

01180 G=ALDG 0 (H)

0) $190 \mathrm{H}=\mathrm{G} \bullet \bullet$. 


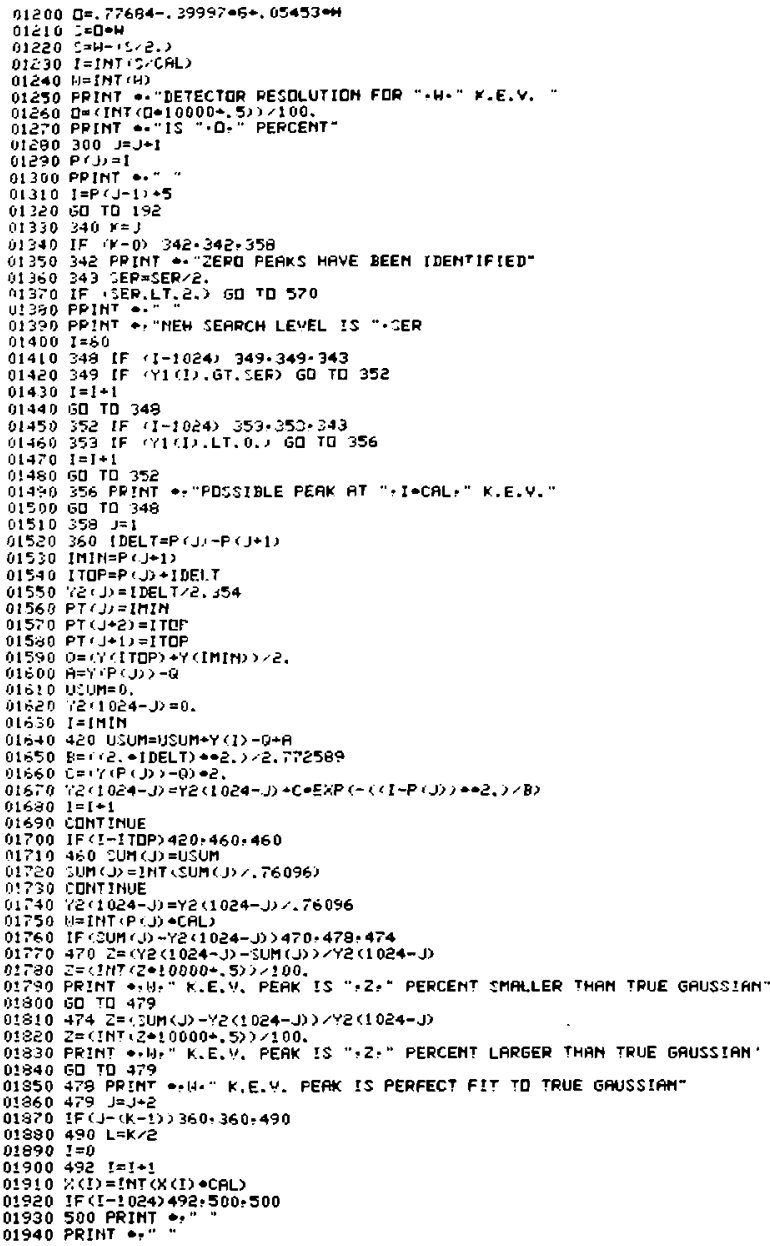




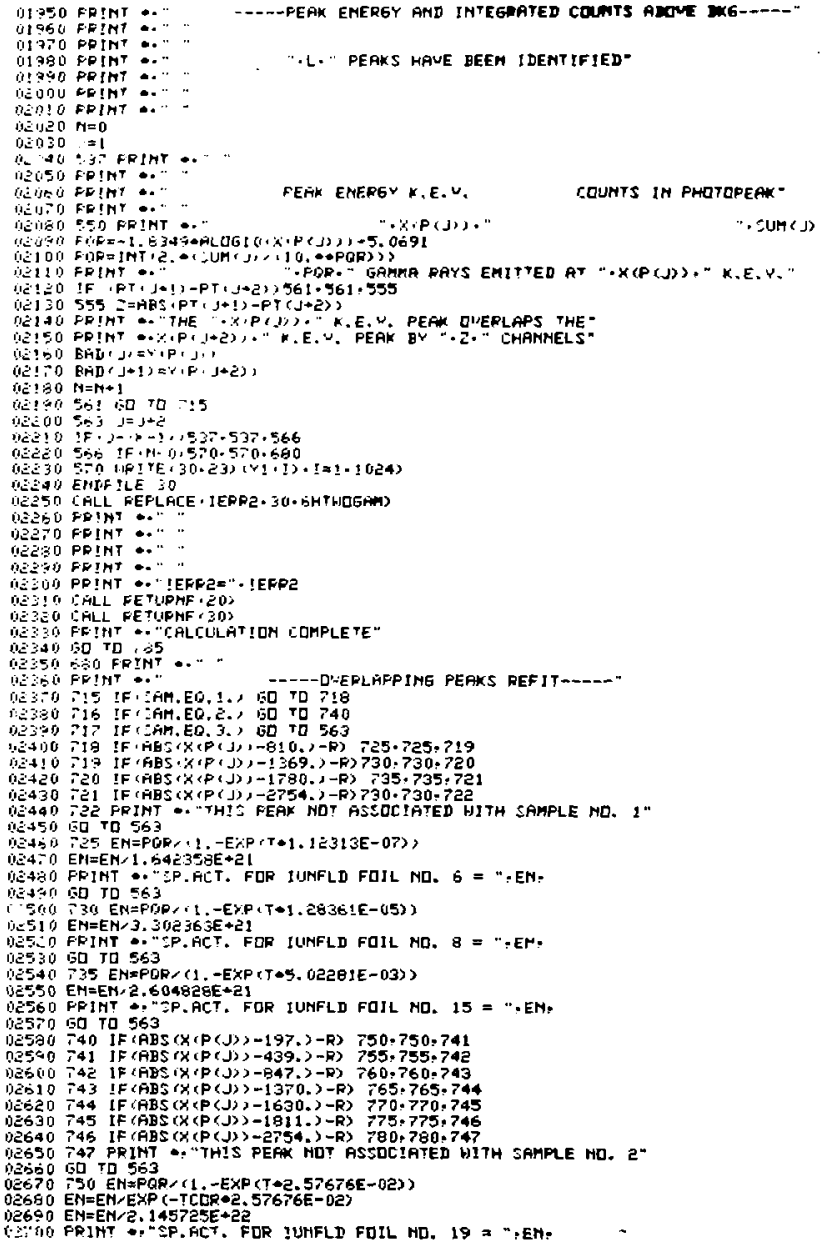


0 Dट710 6D TD 563

GETZO TS5 EN=PQR (1.-EXP(T-1, E241E-02)

UeTJ0 EN=EH

02740 EM=EM-2, $212058 E+22$

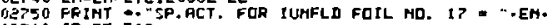

OEF 60 GQ Td $\$ 63$

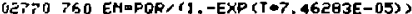

02780 EN=EH/2.50549jE-2己

OËG0 PPINT : TF.ACT. FIR IUNFLD FOIL ND. $7=\cdots$.EN.

$0280050 \mathrm{T0} 563$

OEEIO 755 PRINT \&. "YHIS PEAK IS DECAY COMBIMATIOH OF FOILS 6 FMD I7"

$0 \sum 8 E 0$ G0

DES30 770 EN=PAR/ (1. -EXP (T॰S. 08024E-02)

(J2B40 EH=EN-EXP (-TCRR・6. 0B02AE-02)

JEE50 EN=EN/2, $215088 E+25$

JEZEO FPINT ‥SP,FCT. FDR IUMFLD FOIL MD. $18=\cdots$-EM.

DEATO 50 TO 563

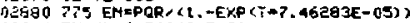

05890 EH=EH/2, 50249IE-23

02900 EH=EH/. 29

02910 PPIHT :- SP. ACT, FOR IUNFLD FOIL NJ. 7 ".EN,

OEFE0 150 TO 563

(12) 30780 EN=POR $(1 .-E K P, T-1.2836(E-05))$

$02 \div 90 \quad E H=E N / 1.730504 E+22$

OLGS PRIAT - "SP.ACT. FOR IUHFLD FOIL ND. $\theta=" ., E H$.

0290 GD TO 563

DESTO 785 cant IMUE

UCOSO EMD

READY.

E'IE
1t. है. th $50 / 03 / 0$.
OFF LIIKFU:E
TTY ij.5
1.000 ¿RU 
Th, coilc PFAKDAT is a photoneale analysta routle for Nal. The code is useful only if a thorough rharacterization is made of the detector uged. It fo conventent to break the deteclor resprinse in'o threc quantiles which car easlly be determined experimentally: resolution (FWHM phetopurir as is function of erergy). Peak-to-total-ratio (ratio counts in photopeak to total caunts). and deter for efficiency.

Sine the majority of the $y$ - mys observet are less than 3 Mov, the MCA is limiteu to 3 MeV

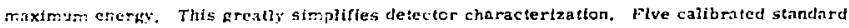
;-ray snures were dised to Icterminc detector response. The sources and y-iay eneraies are listeu in 2alis 21$]$.

TAIBLE B1

$$
\text { Sources and } \gamma \text {-ray Energies }
$$

\begin{tabular}{|c|c|c|}
\hline Source & $\gamma$-Ray E & Energy \\
\hline${ }^{1.37} \mathrm{Cs}$ & 661.2 & $\mathrm{KeV}$ \\
\hline${ }^{54}$ XIn & 835.0 & $\mathrm{keV}$ \\
\hline${ }^{65} \mathrm{Zn}$ & 1,114 & MoY \\
\hline $22 \mathrm{Na}$ & 511 & KeV \\
\hline${ }^{22} \mathrm{Sa}$ & 1.274 & $\mathrm{MeV}$ \\
\hline${ }^{50} \mathrm{Co}$ & 1.17 & MeV \\
\hline $\mathrm{Co}$ & 1.33 & $\mathrm{MeV}$ \\
\hline${ }^{60} \mathrm{Co}$ & 2.50 & $\mathrm{MeV}$ \\
\hline
\end{tabular}

$\gamma$-rat spectrum from each of the isotopes are measured. The system is calibrated to $3.0 \mathrm{zel} /$ channel, using a ${ }^{60} \mathrm{Co}$ source and an Ortec $4 \mathrm{l9}$ preciston pulse generator. From the raw data, the location of cach photopeak and count in that channel are recorded. The channel locations at half the peak count are then recorded. Whera these points are between channels, linear interpolatics is used to deternine fractional parts of a channel. The full-width-half-maximum for each photopeak is then found by multiplying the differance in channel numbers by the calibration of $3 \mathrm{keV}$ ichannel.

A plot of this detector resolution data appears as a concis a upward curve on semilog paper. $\%$-ray energy on a log scalc vs resolution expressed as a percent is found by dividing FWHM value by fill photopeak energy. A convenient function for detector resolution can therefore be generated by a nonlinear, least-squares fit of the data to the form of Equation (BI).

$$
R=a_{0}+a_{1}, \log (E)+a_{2}(\log E)^{2}
$$


The Normad Equationa for aolution are:

$$
\begin{aligned}
& B_{1}=N a_{0}+B_{2} a_{1}+B_{3} a_{2} \\
& B_{G}=B_{2} a_{0}+B_{3} a_{1}+B_{4} a_{2} \\
& B_{7}=B_{3} a_{1}+B_{4} a_{1}+B_{5} a_{2}
\end{aligned}
$$

where:

$$
\begin{aligned}
& x=\text { number of mengurct valucs } \\
& B_{1}=5 R=\text { sum of resolution walues } R \\
& B_{2}=5, \text { log } g_{10}(E)=\text { sum of log of photopeak energiles } \\
& H_{3}=\left(1 \log _{10} \mathrm{E}\right)^{2} \\
& H_{4}=\left(\log _{10} E\right)^{3} \\
& H_{5}=\sum\left(\operatorname{LOB}_{10} E\right)^{4}
\end{aligned}
$$

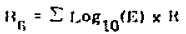

$$
\begin{aligned}
& 13_{7}=5\left(\mathrm{Lag}_{10}(\mathrm{E}) \times \mathrm{H}\right)^{2}
\end{aligned}
$$

The Normal Equations are solved for the coefticionts in Equation (BI). Detector refolution le then calculated by the routine between lines 1170 and 1220 in the PEAKOAT code.

By calculating the peak-10-total-ratio of the ${ }^{137}$ Cs spectrum and knowing the calibrated activity of the soures, I found the dostctor sfiriency to be 51 percent. I aesumed this effleiency would remain constant with energy. This, of courge, is not the case but the diffecence can be accounted for in the peak-to-total function.

Wsing the total counts in a photopeak. the assumed efficiency value and the known source activities, peak-to-total ratios are calculated for each peak. Again. Equation (BI) is solved for the functional form of the peak-to-total ratio vs energy.

The code PEAfiDAT operates as follows:

a. The raw counts/channel MCA data is written into a file.

b. The lile is loaded into an array and smoothed;

c. A first derivative is taken of the smoothed data.

d. The code then begins looking for a first derivative value above some search levcl (SER) 


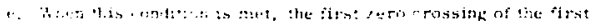

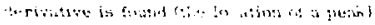

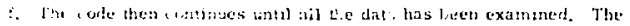

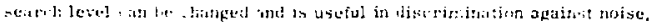

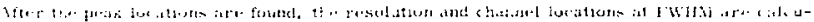

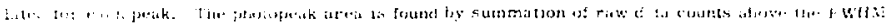

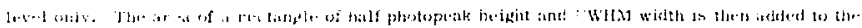

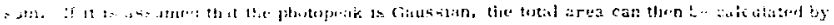

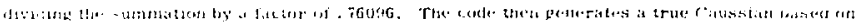

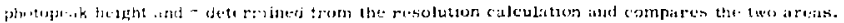

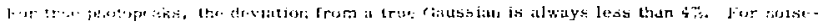

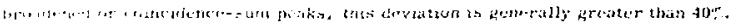

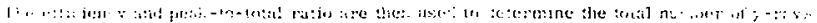

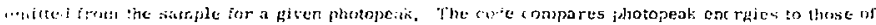

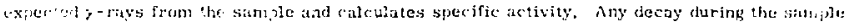
transfer tis:a is correcterl.

The activities relurned lu IJEALAT for the eight calis ration-source energies were sill

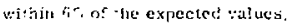

Several years ago, $\mathrm{V}$. Kiggs and D. Amos oi Sandid developed program LXFOיD to solve

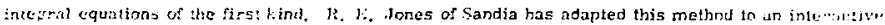

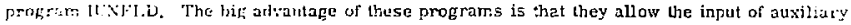
information and do not specifically need a trial spectrum. The code is mathematically riburouj and his the usantage of heing interactive.

Ai mantioned in thetion l, IUNFL, represents $Q(E)$ as a linear sum of basis functions. The bast's ednctions are artually is splines:

$$
r_{i}=\sum_{j=1}^{N} c_{j} \int_{i_{-1}}^{F_{h}} D_{j}\left(E^{*}\right) \sigma_{j}(E) d E=\sum_{j=1}^{j} c_{j} A_{i j} .
$$

which results in a system of linear equations. The integral has a fixed value (A $A_{\text {ij }}$ for each $D_{j}(E) \sigma(L)$. In mitrix form 1 least-square solution of the vector $C$ is requized when $A C=G$.

letivatuon detit is weighted according Le its accuracy by dividing each row of the A matrix and $G$ vector by the esimintes error in G. A smaber errur in the activation data therefore results 
Is a larger weight. These estlmated errors ar: propagated and used in statistlcal tests; the golution accuracy statietice are avatlable as part of the output package.

In order to fit the code tnto allotted flle space of the time-ahare aystem and to provide the Interactive capablilty, the code it hroken into several flles. A procedure flle ILNPR2 attaches the complled binary UNFOLD rile IURLG2 and R flle.

\section{IUNPR2}

IF IF ILE (R . , HUT, LUD > GET , R.

EEWIND: P.PBIH.

$F T H=I=R: B=P B I N$.

ATTAEH: IUNLGENUN=REJDMES.

ATTACH: CSL I B UYALLI BRARY.

LIERFPY: CSLIE.

LCAD. IUMLG2.

LOAD, PBIN.

EYECUTE.

IJILQAD: IUHLGE, RBIH.

CDMMENT. IUHFLD EXECUTION COMFLETED. GDDDBYE. PEADY.

The $R$ file is deaignated by the user to hegin code execution;

-IUNPR2( $\mathrm{R}=$ SPLOOK)

This file retrieves the activation eross-Bections library, contains the format to read the ftle, and calls the FINTRP interpolation routine to gencrate cross sections at energics between those in the library.

SPLOOK

FUHCTION R(T, I)

DIMENSIDN XSAVE (70: 22) : YSAYE (70, 2E) : N (2E)

COMHDN INPUT $\triangle$ (6D)

DATA INIT OU

IF (INIT.EQ.1) GD TD 10

INIT $T=1$

CHLL GETF ( IERR - 21 : 5HSPCTR)

IF (IERR. NE. O) STQP 21

PEVIIND 21

Do $5 \mathrm{~K}=1: 22$

$J \Xi=0$

1

$J L=J E+1$

$\mathrm{j} J=\mathrm{J1}+\mathrm{s}$

PEAD (21,20) (XSAVE (J:K):YSAVE (J,K):JEJ1,J2)

2

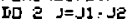

2 IF (XISANE $(J: K), E Q, 0)$ GO TO 3

GD TO 1

H(K) $=J-1$

3 CONTINUE

10 CFLL RETURHF

$P=F$ INTRP $\langle T$ + XSAYE $(2, M)$, YSAVE $(1, M)$ + $(M), 0\rangle$

IF (R.LT. 0.) $R=0$.

20 FURMAT (F1 0.4,5F 12.4)

RETURH

PEADY.

END 


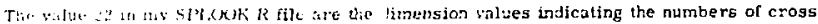

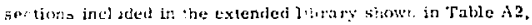

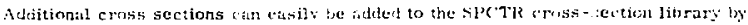

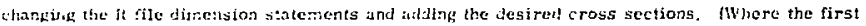
entry is enetgr in liel, the erosis section follow's in harns, in example of a !PCTR printout follow: :

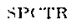

\begin{tabular}{|c|c|c|c|c|c|}
\hline 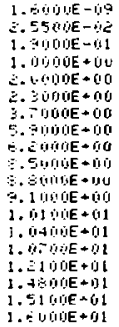 & 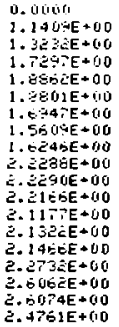 & 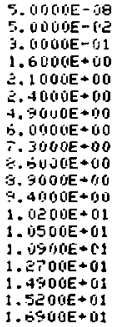 & 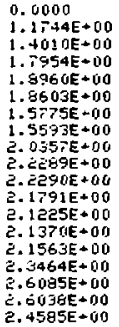 & $\begin{array}{l}1.0000 E-05 \\
1.0000 E-01 \\
5.7500 E-01 \\
1.9000 E+00 \\
2.2000 E+00 \\
2.8000 E+00 \\
5.8000 E+00 \\
6.1000 E+00 \\
3.2000 E+00 \\
3.7000 E+00 \\
1.0000 E+00 \\
1.0000 E+01 \\
1.0300 E+01 \\
1.0600 E+01 \\
1.1500 E+01 \\
1.3900 E+01 \\
1.5000 E+01 \\
1.5300 E+01 \\
1.7900 E+01\end{array}$ & $\begin{array}{l}5.23 r 3 E-08 \\
1.2406 E+00 \\
1.5136 E+00 \\
1.3694 E+00 \\
1.8982 E+00 \\
1.7841 E+00 \\
1.5644 E+00 \\
1.5872 E+00 \\
2.2287 E=00 \\
2.2290 E+00 \\
2.2275 E+00 \\
2.1129 E+00 \\
2.1273 E-00 \\
2.1419 E+00 \\
2.2116 E+00 \\
2.5438 E+00 \\
2.6089 E+00 \\
2.5869 E+00 \\
2.4443 E+00\end{array}$ \\
\hline
\end{tabular}

hs mentioned, the code is inte ractive allowing convenlent entry of an input data file from a given set of measurements. The code is started by execution of the procedure file IUNPR2 and the correct it ille designution based on cross-section library aize. The code then allows a fite to be Liilt from new input.

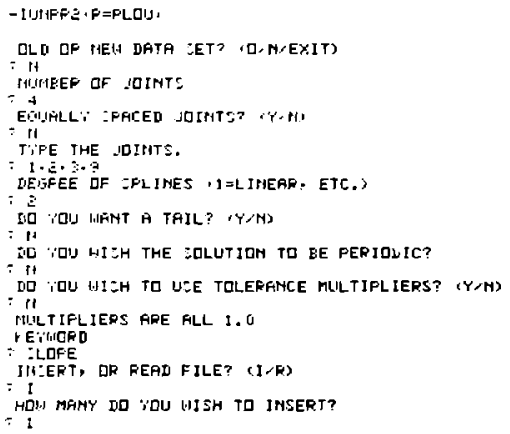




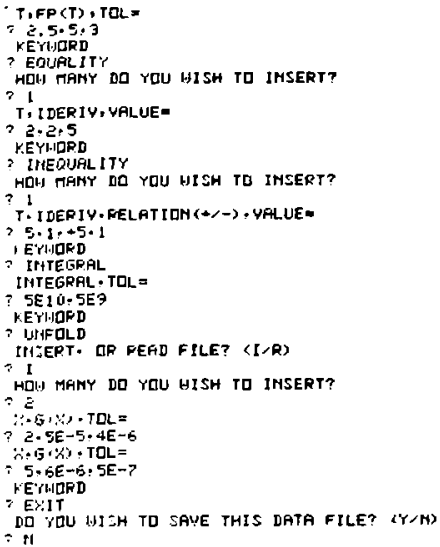

Typical input parameters from the REB neutron dlagnogtics are shown in the preceding printout. Nonsense input was entered to proceed rapldiy through the input stateraents. There a re additional input options available but these inputs typically cannot be generated from the TOF and total yield detectors.

As an example of solution data, a solution by J, M. McKenzie is presented. Here, 13 activation measurements, by Mearon ${ }^{1 B}$ et al from the White Sands Missile Range Fast Burst Reactor, were used to calculate the differential neutron spectrum. Specific activation was entered in units of $10^{-12}$ nuclides/tuclide so that the fluence values in the following printout do not have exponents. The spectral solution and the differential and integral statistics are glven.

The $X$ ard $G$ values are the cross-gection file foil numbers and the specific activities, respectively. All other input and output are self-explanatory. 


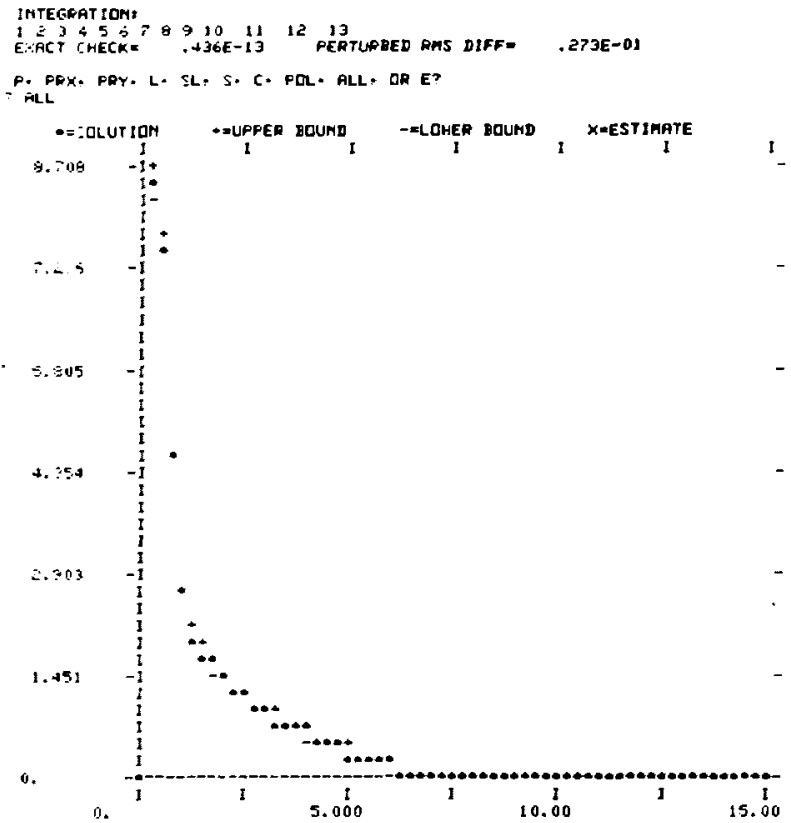

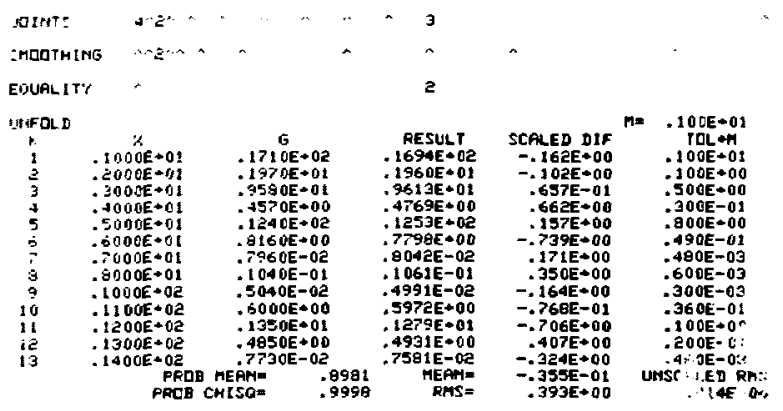




$$
\begin{aligned}
& \text {. 5000E-01 } \\
& \text {. } 2000 \mathrm{E}+0 \mathrm{O} \\
& \text {. } \$ 000 \mathrm{O}+00 \\
& \text { - 5\%OOE+OO } \\
& \text { - FoOE +00 } \\
& \text { - 9000E } 00 \\
& \text { - } 1460 E+01 \\
& \text { - } 2500 E+01 \\
& \text { * } 500 \mathrm{OE}+\Delta 1 \\
& .700 D E+01
\end{aligned}
$$

$$
\begin{array}{r}
\text { RESULT } \\
-.1077 E+04 \\
-.6976 E+02 \\
-.7196 E+02 \\
-.2331 E-01 \\
.1791 E+02 \\
.2062 E+02 \\
.4969 E+00 \\
.2975 E+00 \\
.1413 E+00 \\
.2045 E-01 \\
.5000 E-02 \\
\text { HEAHE } \\
\text { RHSO }
\end{array}
$$

INTEGRPL

10.

RESULT $.1069 E+02$ MEAH: PMS

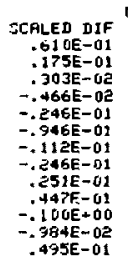

$M=.100 E+02$ TaLA $.219 E+03$ $.140 E+02$ $.140 E+02$ $.500 E+01$ . 35OE - DI $.400 E+01$ $.100 E+00$ $.100 E+00$ $.500 E-01$

$.100 E-01$ . ZOOE- IJ UHSCFLED FMS . SOJE-04

$\mathrm{H}=.100 \mathrm{0}-01$

ICALED DIF

$.158 E+00$ $=158 E+00$ $.159 E+00$
FFIA MEANE $\$ 3743$ FPOE CHISO 